NBER WORKING PAPER SERIES

U.S. TAX POLICY AND DIRECT INVESTMENT ABROAD

$$
\text { Joosung Jun }
$$

Working Paper No. 3049

NATIONAL BUREAU OF ECONOMIC RESEARCH

1050 Massachusetts Avenue

Cambridge, MA 02138

July 1989

Presented at the NBER conference on International Aspects of Taxation, February $23-25,1989$. This paper is part of NBER's research program in Taxation. Any opinions expressed are those of the author not those of the National Bureau of Economic Research. 
NBER Working Paper \#3049

July 1989

\section{U.S. TAX POLICY AND DIRECT INVESTMENT ABROAD}

\section{ABSTRACT}

The analysis presented in this paper shows that U.S. tax policy can have significant effects on U.S. direct investment outflows through various channels. It is stressed that a sensible choice of specification and data in an empirical model entails a rigorous examination of the theoretical underpinnings behind the model. In particular, we emphasize the difference between foreign fixed investment undertaken by the foreign subsidiary and direct investment of the entire international firm, and the need to use different theoretical frameworks in each case.

We present estimated equations relating the balance of payments direct investment outflows -- distinguishing between retained subsidiary earnings and parent transfers -- to various measures of the U.S. net rate of return and the cost of funds. The evidence shows that U.S. tax policy toward domestic investment has an important effect on direct investment outflows by influencing the relative net rate of return between the U.S. and abroad. We estimate that a 16 cent reduction in transfers made by U.S. parents firms occurs for every dollar increase in U.S. domestic investment. In contrast to previous studies, transfers equations fit much better than retained earnings equations for every net return variable used in our estimation. of the various specifications tested, the transfers equation containing a marginal, forward-looking and corporate-investor net return variable fits best, a result which is consistent with the predictions of our theoretical framework.

Joosung Jun Department of Economics Yale University 28 Hillhouse Avenue New Haven, CT 06520 


\section{Introduction}

The impact of tax policy on the process of capital accumulation has long been an important subject of policy debates and academic research. The tax policy debate in the 1980s has been largely motivated by a concern over the rate of capital accumulation in the U.S. Tax rules can affect the nation's capital formation by influencing the return to saving and to investing in plant and equipment. However, the presence of international capital mobility requires policymakers to design tax incentives from a different perspective from that which would be taken in the case of immobile capital. Savings incentives and investment incentives can no longer be treated as alternative devices to enhance domestic capital formation. Part of domestic savings may flow into investment projects abroad while domestic investient incentives can bring in more foreign capital. If long term capital in particular is mobile across national boundaries, a country with higher domestic tax rates will drive domestic businesses abroad while a country with generous investment allowances will attract more investments in plant and equipment. 
Several theoretical papers have suggested that international capital mobility would have important implications for the welfare effects of tax policy (e.g. Gorden 1986, slemrod 1987, and Giovannini 1988). Using a general equilibrium simulation model, Goulder, Shoven, and whalley (1983) have shown that the effects of elastic foreign investment flows could dominate other effects of tax policy on welfare. Summers (1986) shows that international capital mobility can have potentially significant implications for the effects of taxes on international competitiveness and the current account.

Despite the importance of knowing the elasticity of international capital flows with respect to rates of return, however, very few attempts have been made to measure it. Hartman (1981, 1984) reports significant elasticities of direct investment flows with respect to U.S. net return variables. Using updated investment data and tax variables, Boskin and Gale (1987) provide estimates which also confirm the basic conclusions in Hartman's studies. While these studies represent the first serious attempts to estimate elasticities, their estimation seems to be subject to measurement problems, as discussed later.

The profit-maximizing international firm will try to optimize over the capital allocation between the parent and subsidiaries, given different rates of returns and sources of funds between countries. An empirical analysis of the tax 
effects on international capital flows entails a thorough theoretical examination of international firm behavior and the intertemporal, intercountry and intercompany nature of direct investment. The lack of rigorous theoretical frameworks from which testable implications can be drawn, combined with various data problems, has contributed to the sparseness of reliable empirical evidence in this area.

The purpose of this paper is twofold. First, we attempt to estimate the sensitivity of U.S. direct investment capital outflows to the U.S. net rate of return. Our second and more general goal is to address various potential misrepresentation problems with empirical models in this area. Such problems are partly due to the absence of reliable data and to the lack of reliable theoretical underpinnings.

The paper begins in section 2 with a brief theoretical discussion of various channels through which domestic tax policy can affect the home country firm's direct investment abroad. Section 3 discusses issues related to using existing direct investment data in an empirical model and stresses the importance of a theoretical structure in choosing a proper model. Section 4 presents our empirical model, which is based on the theoretical framework developed in section 2 , and our estimation of equations which relate U.S. direct investment outflows to the domestic net rate of return. A brief summary section follows. 
2. A Theoretical Framework

The present section heuristically investigates three major channels through which domestic tax policy can affect the home country firm's international direct investment. A more rigorous treatment of this issue is presented in Jun (1988). First, the tax treatment of foreign source income will have a direct relevance to the net profitability of foreign investment. Tax rules applied to foreign source income include the corporate tax rate, the foreign tax credit, and the deferral of home country taxes on unrepatriated foreign source income. Second, tax policy can affect the relative net profitability of investments between different countries. Specifically, home country tax policy instruments toward domestic investment, such as the corporate tax rate, the investment tax credit and depreciation allowances, will affect net domestic returns and accordingly the relative net profitability between domestic investment and foreign investment. Third, tax policy can affect the relative net cost of external funds between different countries. Since the international firm can raise funds both at home and abroad, tax rules which affect the domestic net cost of funds such as the tax deductibility of interest, will influence the relative net cost of funds between countries and therefore the flow of investment funds. 
Tax policy toward foreign source income has long been a subject of policy debate and political controversy. Most of the existing literature is also concerned with this aspect of the tax effects on international capital movements. One major concern regarding international investment is the possibility for foreign source income to be taxed twice, once by the host country government and again by the home country government. In many industrial countries including the U.S., a credit or deduction is allowed for taxes paid to the host country government in an effort to avoid double taxation. Furthermore, the home country tax can be deferred until foreign source income is repatriated to the domestic parent. Tax deferrals combined with the foreign tax credit can have a significant impact on the international firm's investment and financial decisions.

A central issue in evaluating tax policy towards foreign source income concerns the firm's method of financing marginal foreign investment. Foreign operations can be financed in several ways. The most explicit form is the transfer of funds to a foreign subsidiary by the domestic parent. These parent transfers consist of equity investments and intercompany loans. The retention of earnings by the foreign subsidiary is another major source of funds. In fact, the sum of these two financing sources -- parent transfers and retained earnings -- is the definition of direct investment in the balance of payments data.' 
The effect of tax policy on foreign investment is highly dependent on whether parent transfers or retained earnings are assumed to be the marginal source of funds. Traditional researchers either have ignored retained subsidiary earnings or have assumed a fixed dividend payout ratio so that they can regard parent transfers as the marginal source of financing foreign investments. In this case, while the home country tax affects foreign investment, the deferral of taxes on retained earnings will reduce the effective tax rate on foreign investment below the home country rate, favoring capital outflows, if the home country tax rate is higher than the host country rate. Hartman (1985) challenges this view by demonstrating that deferred home country taxes are capitalized in the market value of the subsidiary so that those taxes can have no effect on the firm's new investment decision. Since in this case the marginal cost or the equilibrium shadow value of capital is smaller than in the parent-transfer case, Hartman argues, retained earnings must be the optimal marginal source of funds whenever feasible. This tax capitalization view has the strong policy implication that any special taxes on foreign source income have no effect on the marginal investment decision of mature subsidiaries with after-foreign-tax earnings in excess of desired investment expenditures.

Understanding the tax effects on international direct investment requires a proper model of subsidiary behavior since 
foreign investment is eventually undertaken by a foreign subsidiary. One might be tempted to treat the subsidiary, as many previous studies implicitly do, like the domestic firm which maximizes its market value given the rate of return required by the shareholders. If we solve the subsidiary's maximization problem given an exogenous rate of return required by its shareholder -- the parent --, the resulting expressions for the cost of capital or the effective tax rate will summarize the contrasting views between the two existing positions regarding the marginal source of funds. With retained subsidiary earnings as the marginal source of funds for foreign investment, the effective tax rate is simply the host country tax rate reflecting the capitalization of the home country tax into the subsidiary value. Under the more traditional transfers regime, the effective tax rate will be a weighted average of the home and host tax rates in which the weights are the dividend payout ratio. ${ }^{2}$

Although the practice of isolating the subsidiary's maximization problem is a convenient way of studying foreign fixed investment undertaken by the subsidiary or of summarizing the effects of tax policy toward foreign source income on direct investment, ${ }^{3}$ it can be quite misleading when we try to understand the overall effects of the home country tax system on direct investment flows. Tax policy can also affect direct investment through other channels, which can be best analyzed when we 
recognize that the subsidiary is one part of the international firm. Although the parent controls domestic operations in the home country, its major concern is the maximization of the overall profits of the international firm. Thus, to gain proper understanding of international firm behavior and corresponding capital flows, it is imperative to integrate the subsidiary's foreign operation with the parent's domestic operation. The profit-maximizing international firm should optimize over every relevant decision variable -- domestic, foreign, or intrafirm. specifically, in addition to the marginal source of funds for foreign investment, the international firm should optimize over the location of physical investment and the location of external sources of funds.

The second major channel through which domestic tax policy influences direct investment is through its effects on the relative net rates of return between the home country and the host country. The direct investment decision of international firms can be affected by a variety of factors; for example, they establish branches and subsidiaries abroad to secure local markets, to have easy access to raw materials, and to take advantage of lower labor costs. In sum, direct investment arises from

expectations of higher profitability from venturing abroad. Tax policy can influence the decision of investment location by affecting the relative net profitability between different 
countries.

In order to derive the criteria for intrafirm investment allocation, Jun (1988) integrates the subsidiary's foreign operation and the parent's domestic operation by explicitly recognizing the ownership chain of the international firm -- the subsidiary-the parent-the domestic shareholders -- and the relevant rate of return required by each party's immediate owner. specifically, the rate of return used by the subsidiary in discounting its future profit stream is endogenously determined in the model in a way that maximizes the overall profits of the entire firm." In that process, we can sum the tax effects at the foreign source income tax and the relative net return channels and explicitly derive the criteria for intrafirm investment allocation between domestic and foreign operations under each financing regime at the margin. With retained subsidiary earnings as the marginal source of funds, for example, our model predicts that the international firm should invest abroad until the net returns in the home and host countries are equalized; in this case, the domestic tax rate affects foreign investment only by changing relative net returns. Since the relative net return channel itself is independent of the financing regime, the domestic tax system can affect direct investment even under the retained earnings regime.

The paper also shows that the intrafirm allocation criteria 
do not include parameters associated with domestic shareholders, while in the long run the cost of foreign capital can be expressed as a function of the rate of return required by the shareholders. This result implies that although the foreign subsidiary is ultimately owned by the domestic shareholders through the ownership chain, the investment location decision is a purely intrafirm variable which is not directly affected by the shareholders. We call this result the "parent-veil", which can be thought of as a strong form of the corporate veil. In other words, the shareholders will be concerned with the ultimate rate of return on the overall operations paid through the domestic parent, but may not care about transactions within the firm. This parent-veil proposition is supported by evidence presented in section 4 .

The third channel for tax effects on direct investment flows is related to the way taxation affects the cost of external funds for the firm. The discussion of the first two channels focused primarily on issues related to the allocation of funds available within the international firm -- internal funds. ${ }^{5}$ The parent concerned with overall profit maximization will be sensitive to any difference in the cost of external funds between countries. As long as local fund-raising in the host country is feasible and costs less than in the home country, the parent will have an incentive to let the subsidiary rely more on this source and to reduce its transfers. 
Tax rules have always been a central focus of the debate regarding the real effects of corporate financial policy. Since income accruing within a firm and income accruing directly to individuals receive different tax treatments, there is an incentive at the margin for the firm to favor debt financing until the benefits from the tax deductibility of interest payments are matched by the potential bankruptcy and agency costs associated with a higher debt-equity ratio. For the international firm, the possibility of raising funds in different countries can create another opportunity for tax arbitrage. The intuition behind this can be easily illustrated by a simple example. Suppose both the parent and the subsidiary borrow at the margin to raise funds. The cost of funds can be defined as $\operatorname{COF}=(1-t) i$ and $\operatorname{COF}{ }^{\star}=(1-t *) *$ where $i$ and $i \star$ are the interest rates with the asterisk denoting a host country variable. A reduction in the domestic tax rate $t$ would imply that local borrowing in the host country becomes a cheaper source of external funds, other things being equal. As a result, the subsidiary is more likely to resort to local borrowing and less likely to receive transfers by the parent than before. Thus, tax policy can influence international direct investment by affecting the relative cost of funds between countries.

This relative cost of funds channel has not been recognized in the existing literature but can be quite important in practice, as exemplified in the transactions between the 
Netherlands Antilles finance affiliates and their domestic parents. The next section discusses this example in detail.

The preceding discussion suggests that domestic tax policy can have a significant effect on direct investment flows through various channels. What are the implications of our theoretical framework for empirical work in this area?

First, the multi-channel analysis suggests that empirical work specify which tax channel, which decision of the firm or which tax policy it focuses on. Note that the relative net return channel and the relative net cost of funds channel are concerned with the choice of location between the home country and the host country. On the other hand, the fact that U.S. international firms' global income is subject to domestic taxation implies that application of the U.S. corporate tax rate to foreign source income is related to the international firm's overall investment. Thus, while the reduction of the domestic corporate rate may increase foreign investment through its impact on overall investment (the first channel), it will have negative allocative effects on foreign investment by increasing domestic net returns and the net cost of funds (the second and third channels). In addition to emphasizing the different ways a given tax policy affects investment, this multi-channel analysis also facilitates the evaluation of different types of tax policies. For example, the foreign tax credit, the investment tax credit or 
depreciation allowances, and the tax deductibility of interest payments affect international investment through different channels. ${ }^{6}$

Second, the choice of an empirical model and relevant data should be consistent with the implications derived from a theoretical model. In most previous studies, foreign investment undertaken by the foreign subsidiary and direct investment of the international firm are treated as equivalent. Specifically, previous studies employ the balance of payments direct investment flows as a proxy for foreign fixed investment undertaken by the subsidiaries. In practice, however, these two concepts can deviate from each other significantly; this difference gives rise to the need to reexamine the empirical methodology employed in existing studies.

3. Direct Investment Data

International direct investment implies that an investor in one country has a controlling interest in, and therefore a degree of influence over the management of, a business enterprise in another country. Specifically, direct investment involves the establishment of a new enterprise or the acquisition of an existing enterprise and a lasting control of these facilities in a foreign country. What constitutes a controlling interest can 
vary case by case and thus is defined somewhat arbitrarily. The U.S. Department of Commerce defines controlling interest as ownership or control of ten percent or more of the voting securities or an equivalent interest of a foreign business enterprise.' Any investment abroad that is not direct investment is considered portfolio investment.

The most frequently investigated data on direct investment are the Commerce Department balance of payments (BOP) direct investment flows -- both U.S. direct investment abroad and foreign direct investment in the U.S. The BOP items consist primarily of transactions between parents and their affiliates. Specifically, direct investment capital outflows consist of equity capital outflows, intercompany debt outflows, and reinvested subsidiary earnings. Note that we sum the first two items as parent transfers in our study.

one major reason that the recent trends in BOP direct investment flows have become an important policy concern is their implications for capital formation in the U.S. Table 1 shows that BOP direct investment inflows in 1979 and outflows in 1981 each reached about a quarter of U.S. net domestic investment in plant and equipment. Moreover, there has been a dramatic change in the direction and magnitude of these flows in the early 1980 s. Although the first half of the 1980 s was a period characterized by a series of unusual economic events -- high real interest 
rates and a deep recession, a sharp appreciation and later depreciation in the real value of the dollar, and huge budget and trade deficits, the changes in investment incentives enacted in the tax legislation both in the early 1980 s and in 1986 have evoked concern over the nature and extent of the influence of tax policy on international flows.

Specifically, in the 1980s, the direction of BOP direct investment flows roughly coincides with what the relative net return channel implies. In the early 1980s, when various investment incentives were enacted in tax legislation (the Economic Recovery Act of 1981 and the Tax Equity and Fiscal Responsibility Act of 1982), the ratios of direct investment outflows to domestic net nonresidential fixed investment dropped significantly while the corresponding ratios for capital inflows increased substantially. ${ }^{8}$ Note that the conventional wisdom in the early 1980s held that with the extremely overvalued dollar, U.S. firms would lose competitiveness and thus invest abroad instead of in the U.S. The coincidence between tax changes and international investment flows occurred again in 1986. The 1986 Tax Reform Act abolished many favorable incentive provisions like the investment tax credit or the Accelerated cost Recovery system. Seemingly in response to this tax change, U.S. direct investment abroad bounced back sharply in 1986. The similar surge in foreign direct investment in the U.S. may seem counterintuitive, but it accurred mainly because foreign firms 
tried to take advantage of the favorable incentive provisions before their expiration at the end of the year.

Notice, however, that the BOP direct investment measures may not exactly represent the foreign-equivalent of domestic investment figures. Therefore, the denominator and the numerator of the ratios presented in Table 1 may not be comparable. In fact, the BOP direct investment flows can be most accurately regarded as financial transactions between affiliated parties and therefore do not necessarily represent real capital expenditures by foreign affiliates. To the extent that foreign subsidiaries resort to unaffiliated sources of funds like local borrowing, the BOP direct investment measures underestimate real foreign investment. On the other hand, to the extent direct investment flows do not finance real purchases of investment goods, the BOP figures overestimate real foreign investment. Therefore, these BOP figures cannot be regarded as the exact foreign-equivalent of net domestic fixed investment and consequently, use of these numbers as a proxy for foreign investment as in Table 1 should be viewed with caution. Nonetheless, citing the offsetting effects mentioned above, previous authors have tried to justify these figures as an alternative for true net foreign fixed investment. ${ }^{9}$ This practice deserves a closer scrutiny.

First, as discussed in detail in Jun (1989a), the BOP flows may seriously underestimate the true degree of foreign interests 
in U.S. assets because of the presence of unaffiliated financing sources -- most importantly local borrowing in the host country. Therefore, even when the BOP flows are all used to finance real long-term investments, these figures will underestimate net foreign fixed investment to some extent. Some authors argue that local borrowing may be mostly short-term in maturity and have little to do with long-term real investment. Using foreign affiliate financial and operating data, however, Jun (1989a) shows that though on average the majority of liabilities are short-term in maturity, long-term debt is as prevalent as shortterm debt for many industries. ${ }^{10}$

Second, part of the BOP flows may have little to do with real productive investments. To the extent that BOP flows do not finance long-term physical investment, these figures will overestimate foreign fixed investment. Such overestimation may possibly offset the underestimation mentioned above. Note, however, that the BOP figures do represent net, not gross flows. Any inflows in U.S. direct investment abroad will be netted against gross outflows. This negative entry can cause no problem as long as it represents decreased foreign fixed investment. However, some foreign affiliates may raise debt capital in the host country and then transfer the proceeds to domestic parents. Such funds can be recorded as negative direct investment abroad in the BOP accounts but have little to do with productive activities. In this case, the BOP figures will 
underestimate net foreign fixed investment.

The most noticeable example of this is the transactions between the Netherlands Antilles finance affiliates and their U.S. parents. These finance affiliates have been established to provide U.S. parents with a means of raising funds abroad without having the associated interest payments subjected to a 30-percent U.S. withholding tax on interest payments to foreigners. Since 1977, the funds reloaned to U.S. parents have been included in the BOP accounts as negative U.S. direct investment abroad. Table 2 summarizes total U.S. capital outflows and the transactions with Netherlands Antilles finance affiliates for the last several years. Note that parent transfers are composed of both equity investment and intercompany debt flows. In 1982, for example, the negative debt flows vis-a-vis Netherlands Antilles affiliates can explain most of the total change in that category. It is not hard to see that these debt flows substantially contributed to reducing total BOP U.S. direct investment abroad in some years, especially in the early 1980s. The U.S. withholding tax was repealed in July 1984 and the Netherlands Antilles intercompany debt accounts began to show positive entries since 1985, implying that U.S. parents have been paying off debts to the affiliates.

Besides the reasons mentioned above, there are a host of other factors that may contribute to the skepticism about any 
meaningful comparison between the BOP flows and domestic fixed investment figures including book valuation practices, depreciation calculations, changing coverage of surveys, and exchange rate fluctuations. ${ }^{12}$

Considering all these factors, we believe that the best strategy for utilizing existing investment data is to explicitly distinguish between the foreign investment undertaken by the subsidiary and the direct investment of the international firm, and to develop empirical models based on distinct theoretical considerations in each case. First, if foreign fixed investment undertaken by subsidiaries is the major focus of a study, actual capital expenditures by subsidiaries, rather than the BOP financial flows, is the appropriate data to be used. In this case, the isolation of the subsidiary's maximization problem is a perfectly justifiable modeling strategy, but one must not forget any possible source of funds for foreign investment, especially local borrowing which is not included in the BOP direct investment data by definition. Second, if one is interested in the effects of taxes on international investment capital flows, then the Bop figures are still the best alternative despite the suggested measurement problems. In this case, the more difficult problem is to develop a theoretical framework in which all possible channels for tax effects can be incorporated. It is this second approach that we adopt in this paper. 
One caveat is that in our case, contrary to popular belief, even the inclusion of the Netherlands Antilles transactions in the direct investment figures can be perfectly justified, since those financial transactions are consistent with profitmaximization by the international firm, as discussed in the context of the relative net cost of funds. In reality, in the early 1980s, the Netherlands Antilles finance affiliates could borrow at a lower cost abroad (mostly in Eurobond markets) and transfer funds to U.S. parent firms without incurring the withholding tax on subsequent interest payments. The popular argument against the inclusion of this data in the BOP accounts is based on the inappropriate identification of direct investment flows with real foreign investment undertaken by foreign subsidiaries. This Netherlands Antilles example clearly shows that an adequate theoretical framework is a prerequisite for the correct specification of an empirical model and for the proper utilization of existing data in studying the complex subject of international investment.

\section{Estimation}

The diversity of ways in which domestic tax policy can affect direct investment flows suggests that the evaluation of this subject is ultimately an empirical matter. As discussed earlier, choosing the correct specification and appropriate data 
for an empirical model critically hinges on proper theoretical underpinnings. Since our major focus is on the effects of taxes on direct investment flows, we use the BOP direct investment capital outflows as the dependent variable in our regression analysis. Since the BOP direct investment data basically represents intrafirm transactions between affiliated parties and the tax changes in the 1980 s are largely reflected in the U.S. net rate of return, the main focus of our empirical model is on relative net rates of return. However, unlike previous studies which consider only the net return channel, our model explicitly incorporates the net cost of funds, another channel for the tax effects on the intrafirm allocation of investment funds.

In order to estimate the tax effects on investment flows through the relative net return channel, we need some measure of the net rate of return on domestic investment in the U.S. The conventional method is to use the same net-of-tax return variables as employed in estimation of U.S. domestic investment equations. However, among several available alternatives, not all these variables can be a good candidate for our purposes. Again, as in the case of selecting proper direct investment data, the choice of an appropriate net return variable should also involve rigorous theoretical considerations. specifically, we propose two basic criteria for which a net return variable is to be evaluated. 
First, the variable should capture the relevant incentive effects for firms undertaking marginal direct investment. Often, the marginal net return or effective tax rate differs from the average net return or effective tax rate since incentive provisions like the investment tax credit and accelerated depreciation allowances are relevant only to new investments, not to existing capital. Although the use of the average tax rate has some advantages, like capturing the effects of special provisions or the lack of full loss offset in the tax law, the marginal tax rate is more relevant in capturing incentive effects on marginal investment decisions.

The second and more relevant criterion is related to the intrafirm-transaction nature of direct investment. As discussed in section 2 , one pivotal aspect of international direct investment is the ownership chain of the international firm: the subsidiary-the parent-the shareholders. The decision of investment location is a purely intrafirm variable which is not directly affected by the shareholders. Although the foreign subsidiary is ultimately owned by the domestic shareholders, the "parent veil" seems to be virtually impenetrable. ${ }^{12}$ Thus, the net return measure in our model is supposed to capture the incentive effects on the part of the corporate, not the portfolio, investor. Differences in the measurement of net profitability can be used to distinguish the "corporate-investor" returns from the "portfolio-investor" returns. In a corporate- 
investor model, investment is explicitly made by the corporation. In a portfolio-investor model, on the other hand, the economy is treated like a black box in which investment mechanism is obscure but which produces the plausible result that more capital flows into an asset when the rate of return on that asset is high.

The net return variables used for estimating domestic investment equations first in Feldstein (1982) and recently in Feldstein and Jun (1987) are good examples of these two types. one variable $(R N)$ is the real net-of-tax return received by the providers of debt and equity capital. This RN variable is calculated by subtracting from the pretax return on nonfinancial corporate capital the ratio of the taxes paid by the corporations, their shareholders, and their creditors to the capital stock. Thus, $\mathrm{RN}$ is an example of the average net return since it measures the net return on existing corporate capital. RN is also an example of the portfolio-investor model since it measures the return to portfolio investors. Interestingly, virtually all previous regression studies used this RN variable as the U.S. net rate of return.

The other net return variable (MPNR) is the maximum net return that firms can afford to pay providers of debt and equity capital. This "maximum potential net return" variable can be best interpreted as the internal rate of return of a project in an economy with taxes and inflation. Changes in tax rules, 
inflation, and pretax profitability all alter the maximum potential net return and therefore the incentive to invest. ${ }^{13}$ MPNR differs from RN in two fundamental ways. First, the investment decision is explicitly made by the corporation. Second, this variable measures the prospective yield on new marginal investment rather than the yield on existing capital. MPNR therefore represents the marginal, corporate-investor net return, and consequently better satisfies the two criteria for our model than $R N$, an average, portfolio-investor net return variable.

In an attempt to test the "parent-veil" hypothesis, we also estimate equations with a marginal but portfolio-investor variable. Consider first a very simple economy in which there is no taxation or inflation. Each share of stock claims the ownership of a single unit of capital and the earnings it produces. A simple model of share valuation implies that the price that the individual would be willing to pay per share (QM) would make the marginal product of capital ( $F^{\prime}(K)$ ) equal to the net return he would receive per dollar invested in alternative assets plus a risk premium or simply some required rate of return (R). Then the investor's indifference condition becomes ' $F^{\prime}(K) / Q M=R . '$ From the perspective of the corporate investor, $F^{\prime}(K)$ represents the maximum return he can pay to the providers of capital or the marginal efficiency of capital in the standard textbook model, while $R$ represents the cost of capital or simply 
the rate of interest. In a more complex and realistic economy with taxes and inflation, we can calculate the marginal share value $(Q M)$ by replacing $F^{\prime}(K)$ with the maximum potential net earnings (MPNRE) that can be paid out to the equity investor. Using the MPNR data and a given financial structure (the debtcapital ratio), we can derive MPNRE. As a realistic proxy for the cost of funds (R), we can use some fixed rate of return required by the equity holder or the after-tax safe interest rate plus a risk premium. Jun (1989d) discusses different types of QM series based on various tax assumptions and risk premia. The major point here is that QM uses exactly the same data on earnings, taxes and inflation as used for MPNR, but employs the perspective of the portfolio-investor. Thus, comparison of estimation results for QM to those for MPNR may provide information concerning the parent-veil hypothesis.

Table 3 summarizes the above three variables by their respective characteristics. While previous studies focus only on the $R N$ variable, we estimate direct investment equations using all three net return variables. We expect that among the three variables, the MPNR variable performs best in estimating the tax effects on direct investment flows, since it is the forwardlooking marginal corporate-investor net rate of return. Before reporting the results, however, a few caveats are in order.

First, a significant coefficient on the net-of-tax return 
itself does not necessarily mean that direct investment flows are sensitive to tax changes. Thus, we need a reasonable decomposition of the effect of net return changes into the effect of the change in tax rules and the effect of the change in the pretax rate of return. Unlike $\mathrm{RN}$ which reflects changes both in the pretax return and the effective tax rate, the MPNR variable assumes a fixed pre-tax rate return. Thus, MPNR has a clear advantage in that it focuses on changes in the tax law and in inflation. ${ }^{14}$

Second, in estimating domestic investment equations, Feldstein and Jun (1987) use the difference between the maximum net return that firms can pay (MPNR) and the actual cost of funds (COF). COF is taken to be a weighted average of the costs of debt and of equity funds, with the weights equal to the debtcapital ratios. In estimating direct investment, however, that specification will be no longer valid since U.S. multinational firms can raise investment funds in host countries as well as in the U.S. As shown in section 2, tax changes can influence the intercompany flow of funds by affecting the relative net cost of funds between countries. To the extent that host country external funds (COF*) are cheaper, the parent will have an incentive to have its affiliate depend more on local funds in the host country. Therefore, the correct and complete specification would include 'COF-COF*' and 'MPNR-MPNR*', which represent the relative net cost of funds channel and the relative net return 
channel, respectively. In the absence of the COF* and MPNR* variables, we include only MPNR and COF, of course as separate terms.

Both MPNR and COF should relay some information about the allocative effect of taxes in equations using the BOP direct investment data. However, we expect MPNR, which represents the allocation of internal funds, to explain the BOP data better than COF, which represents the allocation of external funds. The BOP flows -- the sum of retained subsidiary earnings and parent transfers -- can be best interpreted as representing the allocation of internal funds within the entire international firm. As discussed in detail in Jun (1989a), parent transfers may be drawn from external funds (e.g. funds borrowed by the parent from unaffiliated sources), but can be best thought of as internal funds of the parent. Therefore, while we expect a negative coefficient on the MPNR variable in an estimated equation, we do not expect the CoF variable to reveal statistically significant information about the relative cost of fund channel in the absence of $C^{*}$, which is probably more directly relevant to the parent's transfer decision in practice.

Table 4 presents the estimated equations relating the ratio of U.S. direct investment abroad in the balance of payments accounts to GNP to the net return variables discussed above. As in previous studies, we estimate separate equations for the two 
components -- retained subsidiary earnings and parent transfers - of direct investment. This practice allows us to compare our estimates with previous ones and also provides indirect evidence on the marginal source of funds for foreign investment. In all previous estimation studies (Hartman 1981, 1985; Boskin and Gale 1987), only their equations for retained earnings show sensitivity to net return variables. ${ }^{15}$ This result seems consistent with the tax capitalization view that retained earnings should be the marginal source of funds for mature subsidiaries. In Jun (1989b), however, we refute this view using evidence based on individual firm data, and argue that parent transfers should be the marginal source of funds for the majority of subsidiaries.

In each equation, we include the "actual net average return" (RDIA: actual after-foreign-tax direct investment earnings divided by direct investment position) to represent any specific incentives associated with foreign investment which are not to be captured by the domestic net return. This RDIA variable may be regarded as a proxy for MPNR*, possibly mitigating the missing variable bias associated with the net return channel. Since studies generally indicate a lag that peaks at 12 to 18 months between changes in the determinants of investment and subsequent changes in investment, the explanatory variables are one-year lagged as conventionally done in estimation of domestic investment. Note that all previous works 
do not lag the independent variables, an omission which we believe is a major source of problem with their estimations.

As shown in columns (1) and (4), the coefficients on the average yield on existing capital (RN) are very small in size, incorrect in sign, and statistically insignificant. on the other hand, the maximum potential net return for the corporate investor (MPNR) has sizable and correctly signed coefficients as shown in Columns (2) and (4). It suggests that U.S. tax changes can have significant effects on U.S. multinational firms' investment abroad. However, the t-statistics for MPNR in the retainedearnings equation is not large enough to be significant while the $t$ value in the transfer equation is relatively sizable. This fact supports the view that parent transfers are the marginal source of funds for the majority of subsidiaries. In any event, the results also confirm our initial guess that MPNR -- the marginal and corporate-investor variable -- is a more appropriate variable than $\mathrm{RN}$-- the average and portfolio-investor variable - in estimating tax effects on intrafirm investment allocation between parents and subsidiaries.

While even the best net return measure for our purposes (MPNR) fails to have significant coefficients for any retained earnings equation, the transfers equations show consistently higher $\mathrm{R}$-bar squares than their retained earnings counterparts. This result provides indirect support for the claim that parent 
transfers are the marginal source of funds for foreign investment.

Columns (3) and (6) show the estimated equations with the QM variable. Neither equation succeeds in producing significant coefficients. The size of the coefficients are small as in other Q-investment equations, although our $Q$ variables are not based on the adjustment cost function. Considering that MPNR and QM use virtually identical data except that each model is based on different types of investors, this result provides further support to the parent-veil argument.

In all equations, the lagged RDIAs fail to produce any significant coefficients. This result can be contrasted with the significant coefficients on the corresponding variable (RFDI: actual return on foreign direct investment in the U.S.) in similarly defined equations regarding foreign direct investment in the U.S. presented in Jun (1989C). One potential explanation comes from the presumption that RDIA or RFDI is supposed to capture the return on existing investment projects. When we decompose BOP direct investment into 'inflows to existing affiliates' and 'funds used for acquisition and establishment, 16 RDIA or RFDI may be more directly relevant to the first type of funds while the host country net return (the U.S. net return in the case of studying foreign direct investment in the U.S.) may be related more to the latter type. Thus, the 
contrasting performance of RDIA and RFDI might be due to the differential composition of the BOP inflows and outflows between these two types of direct investment opportunities -- new and old. However, a more convincing explanation is related to the RDIA variable itself. As noticed earlier, U.S. direct investment position and income -- the denominator and the numerator of RDIA, respectively -- may be subject to serious valuation problems, such as book valuation of the investment position and currencyconversion effects. The data for the RFDI variable may be subject to fewer problems.

We do not have obtain reliable results for the cof variable; this outcome, however, is not surprising partly because BOP figures are more relevant to the net return channel as discussed earlier, and also because most of the tax changes in question are associated with the profitability of investment rather than with the cost side.

How do these results compare with previous works? Hartman (1981) and recently Boskin and Gale (1987) have estimated the same specification as in columns (1) and (3) using the same type of data -- both investment and tax data --, but they do not lag the explanatory variables at all. For the retained-earnings equations, they typically report very large and statistically significant coefficients on RDIA, and very high R-bar squares (larger than .9 in all cases). ${ }^{17}$ Their transfer equations show a 
very poor fit. These results are in sharp conflict with our theoretical predictions and empirical findings. A closer look at their estimation shows, however, that their significant results seem to be the product of spurious correlation. specifically, for the retained earnings equations, retained earnings data are used to construct both the dependent variable (the ratio of retained earnings to GNP) and RDIA, the independent variable (Retained earnings are the major component of the numerator of RDIA). Our suspicion is also supported by the fact that it is hard to believe that a ninety percent $R$-bar square can be obtained from such parsimonious specification, that the same variable (RDIA) shows such drastically different results in the retained earnings and transfers equations. It is also hard to find serious theoretical arguments for their findings. One caveat is in order. Even if we believe their results, the coefficients of RDIA have nothing to do with the U.S. tax system. so, in fact, they failed to find any "tax effects" on U.S. capital outflows, contrary to their claim.

\section{Summary}

The analysis presented in this paper shows that U.S. tax policy can have a significant effect on direct investment capital flows through various channels. We stress that a sensible choice of model specification and data in an empirical model entails 
rigorous theoretical underpinnings. In particular, we emphasize the difference between foreign investment undertaken by the subsidiary and direct investment of the entire international firm, and the need to use different theoretical frameworks to handle each problem. We present estimated equations relating the balance of payments direct investment outflows to various measures of the U.S. net rate of return. specifically, the evidence shows that U.S. tax policy toward domestic investment can have significant effects on U.S. direct investment outflows by influencing the relative net rate of return between the U.S. and abroad. Among various specifications, the transfers equation including the maximum potential net return (MPNR) fits best, which is consistent with the implications derived from our theoretical framework. Based on these findings and on the estimation of a domestic investment equation with separate MPNR and CoF variables presented in Feldstein and Jun (1987), we can say that a reduction of 16 cents of transfers made by U.S. parent firms occurs for every dollar increase in U.S. domestic investment. The findings in this study also support the claims that parent transfers are the major marginal source of funds for foreign investment and that there exists a strong form of the corporate veil -- the parent veil --between the foreign subsidiary and the domestic shareholders. 
REFERENCES

Boskin, M. and W. Gale (1987), "New Results on the Effects of Tax policy on the International Iocation of

Investment, " in $M$. Feldstein ed. The Effects of Taxation on capital Accumulation, University of Chicago Press, pp. 210-219.

Caves, R. (1982), Multinational Enterprise and Economic Analysis, Cambridge Surveys of Economic Literature, Cambridge University Press.

Feldstein, M (1980), "Inflation and the stock Market," American Economic Review, 70, pp. 839-847.

Feldstein, M. and C. Horioka (1980), "Domestic Savings and International Capital Flows," Economic Journal, 90, pp. 314-329.

Feldstein, M. and J. Jun (1987), "The Effects of Tax Rules on Nonresidential Fixed Investment: Some Preliminary Evidence from the 1980s," in M. Feldstein ed. The Effects of Taxation on Capital Accumulation, University of Chicago Press, 101-156.

Giovannini, A. (1988), "International Capital Mobility and Tax Evasion," mimeo.

Gorden, R. (1986), "Taxation of Investment and Savings in a World Economy," American Economic review, 76, pp. 10861102.

Goulder, L, J. Shoven, and J. Whallay (1983), "Domestic Tax Policy and Foreign Sector," in M. Feldstein ed. Behavioral simulation Methods in Tax Policy Analysis, University of Chicago Press, 333-364.

Hartman, D (1981), "Domestic Tax Policy and Foreign Investment: Some Evidence," NBER Working Paper No. 784.

Hartman, D (1984), " Tax Policy and Foreign Direct Investment in the' United States," National Tax Journal, 37 , No. 4, pp. 475-487.

Hartman, D (1985), "Tax Policy and Foreign Direct Investment, "Journal of Public Economics, 26, pp. 107-121.

Hartman, D (1987), "The Effects of Tax Policy on the 
International Location of Investment: Comment," in $M$. Feldstein ed. The Effects of Taxation on capital

Accumulation, University of Chicago Press, pp.219-222.

Horst, T. (1977), "American Taxation of Multinational Firms," American Economic Review, 67, pp. 376-389.

Jun J. (1988), "Tax Policy and International Direct Investment, " mimeo.

Jun J. (1989a), "Tax Policy and Foreign Direct Investment in the U.S.," mimeo.

Jun J. (1989b), "The Optimal Marginal Source of Funds for Foreign Investment," mimeo.

Jun J. (1989c), "The Effects of U.S. Tax Policy on Foreign Direct Investment in the U.S.," mimeo.

Jun J. (1989d), "Marginal q and Average q: Taxation and Corporate Investment," mimeo, Harvard University.

Lipsey, R. (1987), "Changing Patterns of International Investment in and by the United States, NBER Working Paper No. 2240.

Slemrod, J. (1987), "International Capital Mobility and the Theory of Capital Income Taxation, "mimeo, University of Minnesota.

Summers, L. (1986), Tax Policy and International

Competitiveness," NBER Working Paper No. 2007.

U.S. Department of Commerce (1982), Selected Data on U.S. Direct Investment Abroad, 1950-76, Bureau of Economic Analysis.

U.S. Department of Commerce (1985), U.S. Direct Investment Abroad: 1982 Benchmark Survey Data, Bureau of Economic Analysis.

U.S. Department of Commerce (1987b), U.S. Direct

Investment Abroad: operations of U.S. Parent companies and Their Foreign affiliates, Preliminary 1985 Estimates, Bureau of Economic Analysis.

U.S. Department of Commerce, various issues of survey of current Business. 
1. In practice, local borrowing in the host country can be an important source of financing foreign investment. The presence of local funds may also have implications for the choice between parent transfers and retained earnings at the margin. See Jun $(1989 \mathrm{~b})$.

2. We assume that the home country rate is larger than the host country rate.

3. Note that we explicitly distinguish between foreign investment undertaken by the subsidiary and direct investment made by the parent. Foreign investment can be financed through other sources than direct investment while direct investment may not necessarily finance foreign fixed investment.

4. In equilibrium, the denominator of marginal $q$ for foreign capital is equal to the numerator of marginal $q$ for domestic capital. See Jun (1988).

5. For a domestic firm, internal funds are retained earnings while external funds are raised through new shares and bonds. Similarly, internal funds for an international firm consist of retained earnings of both the parent and the subsidiary.

6. The $\mathrm{Tax}$ Reform Act of 1986 includes provisions reducing the statutory corporate tax rate, repealing the investment tax credit, and restricting the foreign tax credit and tax deferral. The overall effect on direct investment is not evident since these policies can have offsetting effects. However, such a combination of policies may have implications for the composition of investment. For example, relatively more equipment investment may be undertaken by foreign subsidiaries.

7. U.S. Department of Commerce, U.S. Direct Investment Abroad (1985), p.2.

8. The absolute level of direct investment flows also shows the same trend.

9. See Hartman (1984), p. 486 for a summary of previous arguments.

10. In finance, insurance, and wholesale industries, short-term liabilities dominate while in manufacturing, mining, and real estate industries, long-term debt occupies a significant portion of total liabilities (about fifty percent for manufacturing).

11. See Boskin and Gale (1987) for a discussion of potential problems associated with benchmark data. Hartman (1984) correctly argues that the BOP figures can be more comparable to net investment figures since retained earnings are net of depreciation, though is in book value. Exchange rate movements in the early 1980 s may have affected the BOP figures in two ways. First, 
changing relative competitiveness may have influenced direct investment activities. Second, as for U.S direct investment abroad, there may well have been currency conversion effect. Foreign earnings may have been understated when being translated into the dollar value in the early 1980 s when the dollar was highly overvalued.

12. This point is rigorously proved in Jun (1988).

13. We constructed both the constant-profit version (MPNR) and the varying-profitability version (MPNRVP) of the maximum net return. The MPNRVP variable assumes that firms adjust their assumed pretax rate of return from year to year in proportion to that year's actual pretax profitability of capital in the nonfinancial corporate sector. In this study, we use MPNR to focus only on the tax change.

14. See note 13 .

15. We do not even bother to include our replication of their findings since most previous estimation studies share the same basic specification and produce the same qualitative results. We also estimated equations with total direct investment but failed to find any significant covariance effects between the two components of direct investment.

16. Jun (1989a) discusses this issue for foreign direct investment in the U.S.

17. Some of their equations show small but significant coefficients on $R N$ but we failed to have any significant results for this variable using updated data. 
Table 1: Ratios of International Direct Investment to U.S. Net Nonresidential Fixed Investment

\section{U.S. Direct \\ Investment Abroad}

1960.64

1965.69

$1970-74$

$1975-79$

$1980-84$

1979

1980

1981

1982

1983

1984

1985

1986
0.207
0.155
0.195
0.265
0.066

0.255

0.216

0.098

$-0.036$

0.008

0.042

0.160

0.346
Foreign Direct

Investment in the U.S.
0.021
0.021
0.042
0.091
0.239
0.120
0.190
0.256
0.211
0.261
0.276
0.152
0.309

Note: These ratios are calculated by author based on data in U.S. Department of Commerce (1982, 1984), various 1ssues of Survey of Current Business, and the national income and product accounts. 
Table 2: U.S. Direct Investment Abroad and Iransactions with Netherlands Antillean Finance Affiliates.

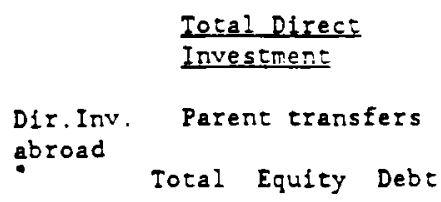

Total Direct

(2) (3) (4)

\section{Necherlands Ancilies \\ Affiliates}

Dir.Inv. Parent transfers abroad

Total Equity Debe

(5) (6) (7)

(8)

$\begin{array}{rrrrrrrrr}1982 & -2.4 & -3.7 & 9.7 & -13.4 & -8.6 & -9.4 & 4.2 & -13.6 \\ 1983 & 0.4 & -6.8 & 4.9 & -11.7 & -3.1 & -4.1 & 1.4 & -5.7 \\ 1984 & 2.8 & -5.7 & 1.7 & -6.9 & -2.0 & -2.8 & 1.0 & -3.8 \\ 1985 & 17.3 & -1.1 & -2.2 & 1.1 & 4.2 & 3.4 & -0.8 & 4.2 \\ 1986 & 28.0 & 9.1 & 0.4 & 8.7 & 5.1 & 5.4 & 1.0 & 4.4\end{array}$

Note: Though we suppress retafned earnings data in this table, they can be obtained by subtracting parent transfers $((2)$ or (6)) from total direct investment ((1) or (5)). 
Table 3: Alternative Net Return Variables

Portfol:o-investor Corporate-investor

Average return

$R N$

Marginal rezurs

QM

MPNR 
Table 4: Estimates of U.S. Dizec Investment Abroad Equations Barent Transfers

Retained Earnings
(1)
(2)
(3)
(4)
(5)
(6)

\begin{tabular}{|c|c|c|c|c|c|c|}
\hline Constant & $\begin{array}{c}0.7 \\
(2.5)\end{array}$ & $\begin{array}{c}6.1 \\
(1.8)\end{array}$ & $\begin{array}{c}0.9 \\
(2.2)\end{array}$ & $\begin{array}{c}0.3 \\
(3.9)\end{array}$ & $\begin{array}{c}0.6 \\
(3.1)\end{array}$ & $\begin{array}{c}0.1 \\
(3.4)\end{array}$ \\
\hline$R D I A$ & $\begin{array}{c}11.0 \\
(11.0)\end{array}$ & $\begin{array}{c}11.9 \\
(11.1)\end{array}$ & $\begin{array}{c}10.7 \\
(10.6)\end{array}$ & $\begin{array}{c}23.7 \\
(25.2)\end{array}$ & $\begin{array}{c}17.1 \\
(26.1)\end{array}$ & $\begin{array}{c}23.3 \\
(25.6)\end{array}$ \\
\hline$R N$ & $\begin{array}{c}4.3 \\
(33.8)\end{array}$ & & & $\begin{array}{c}1.8 \\
(31.0)\end{array}$ & & \\
\hline MPNR & & $\begin{array}{l}-47.5 \\
(33.6)\end{array}$ & & & $\begin{array}{l}-31.9 \\
(38.1)\end{array}$ & \\
\hline COF & & $\begin{array}{c}-7.4 \\
(34.6)\end{array}$ & & & $\begin{array}{c}42.8 \\
(38.7)\end{array}$ & \\
\hline$Q M$ & & & $\begin{array}{l}-0.1 \\
(1.6)\end{array}$ & & & $\begin{array}{c}0.2 \\
(1.4)\end{array}$ \\
\hline$u$ & $\begin{array}{c}0.8 \\
(0.1)\end{array}$ & $\begin{array}{c}0.4 \\
(0.2)\end{array}$ & $\begin{array}{c}0.8 \\
(0.1)\end{array}$ & $\begin{array}{c}0.4 \\
(0.4)\end{array}$ & $\begin{array}{c}0.4 \\
(0.5)\end{array}$ & $\begin{array}{c}0.4 \\
(0.4)\end{array}$ \\
\hline $\begin{array}{l}\text { R-baz } \\
\text { Square }\end{array}$ & 0.634 & 0.671 & 0.634 & 0.398 & 0.407 & 0.399 \\
\hline DHS & 1.85 & 1.81 & 1.82 & 1.85 & 1.73 & 1.85 \\
\hline
\end{tabular}

Note: 1 . Dependent variables are 'retained earnings $\star 1000 /$ L.S. GNP' and 'parent transfers * $1000 /$ U.S. GNP,' respectively.

2. All explanatory variables are one-period lagged.

3. Sample period is 1965-86 for all equations.

4. The equations are estimated with a first-order autocorrelation correction, and the simultaneously estimated autocorrelation coefficient is presented as the coefficient of the variable $u$.

5. Standard errors are shown in parentheses.

6. RDIA: actual net return on direct investment RN: net return on U.S. nonfinancial corporate capltal MPNR: maximum potential net return COF: cost of funds QM: marginal q 